\title{
Genomic interplay in bacterial communities: implications for growth promoting practices in animal husbandry
}

\author{
Piklu Roy Chowdhury, ${ }^{1,}$, Jessica McKinnon ${ }^{1}$, Ethan Wyrsch ${ }^{1}$, Jeffrey M. Hammond ${ }^{2}$, lan G. Charles ${ }^{1}$ \\ and Steven P. Djordjevic ${ }^{1}$
}

${ }^{1}$ The ithree institute, University of Technology Sydney, Sydney, NSW, Australia

${ }^{2}$ NSW Department of Primary Industries, Elizabeth Macarthur Agricultural Institute, Camden, NSW, Australia

\section{Edited by:}

Robert Paul Hunter, Eli Lilly and

Company, USA

Reviewed by:

Patrick Rik Butaye, Ghent University, Belgium

Cristina Lanzas, University of

Tennessee, USA

*Correspondence:

Piklu Roy Chowdhury, The ithree institute, University of Technology Sydney, City Campus (CB04.06) Ultimo, NSW 2007, Australia e-mail:piklu.bhattacharya@ uts.edu.au
The discovery of antibiotics heralded the start of a "Golden Age" in the history of medicine. Over the years, the use of antibiotics extended beyond medical practice into animal husbandry, aquaculture and agriculture. Now, however, we face the worldwide threat of diseases caused by pathogenic bacteria that are resistant to all existing major classes of antibiotic, reflecting the possibility of an end to the antibiotic era. The seriousness of the threat is underscored by the severely limited production of new classes of antibiotics. Evolution of bacteria resistant to multiple antibiotics results from the inherent genetic capability that bacteria have to adapt rapidly to changing environmental conditions. Consequently, under antibiotic selection pressures, bacteria have acquired resistance to all classes of antibiotics, sometimes very shortly after their introduction. Arguably, the evolution and rapid dissemination of multiple drug resistant genes en-masse across microbial pathogens is one of the most serious threats to human health. In this context, effective surveillance strategies to track the development of resistance to multiple antibiotics are vital to managing global infection control. These surveillance strategies are necessary for not only human health but also for animal health, aquaculture and plant production. Shortfalls in the present surveillance strategies need to be identified. Raising awareness of the genetic events that promote co-selection of resistance to multiple antimicrobials is an important prerequisite to the design and implementation of molecular surveillance strategies. In this review we will discuss how lateral gene transfer (LGT), driven by the use of low-dose antibiotics in animal husbandry, has likely played a significant role in the evolution of multiple drug resistance (MDR) in Gram-negative bacteria and has complicated molecular surveillance strategies adopted for predicting imminent resistance threats.

Keywords: multi drug resistance, lateral gene transfer, bacterial genomes, complex resistance loci, Antimicrobial growth promotion

\section{INTRODUCTION}

Antibiotics are central to modern medical and veterinary practice. However, the effectiveness of existing antibiotics in both medical and veterinary practice is under threat due to the rapid rise of multiple drug resistance (MDR) (Gootz, 2010). The 2014 World Health Organisation (WHO) Global report on surveillance of antimicrobial resistance makes this point clear- "A postantibiotic era-in which common infections and minor injuries can kill—far from being an apocalyptic fantasy, is instead a very real possibility for the 21 st century." (WHO, 2014). This possibility was illustrated by antibiotic treatment failure in the 2011 epidemic in Germany in which enteroaggregative Escherichia coli (EAHEC) O104:H4 caused a large outbreak of acute gastroenteritis and haemolytic uremic syndrome. EAHEC O104:H4 is an example of a newly emerged pathogen that possesses novel combinations of acquired antibiotic resistance genes and virulence factors. In the case of EAHEC O104:H4 an enteroaggregative E. coli had acquired a $s t x_{2}$ shiga toxin gene, a characteristic feature of enterohaemorrhagic E. coli genomes, via a bacteriophage (Grad et al., 2013); a plasmid encoded CTX-M-15 gene (encoding the antibiotic resistance factor, extended-spectrum beta-lactamase) (Kunne et al., 2012); and a chromosomally-located complex antibiotic resistance gene cluster, identified recently as the region of divergence 1 (Frank et al., 2011; Januszkiewicz et al., 2011; Ahmed et al., 2012; Radosavljevic et al., 2014). The extensively antibiotic resistant $E$. coli clonal group ST131 is similarly a globally emergent pathogen with novel combinations of acquired antibiotic resistance genes and virulence factors (Johnson et al., 2010; Andersen et al., 2013; Banerjee and Johnson, 2013; Price et al., 2013). Since 2011 there has been an increase in the number of reports describing hybrid $E$. coli genomes with a repertoire of virulence and resistance genes, complicating precise pathotype allocations (Bielaszewska et al., 2014; Prager et al., 2014; Toval et al., 2014). However, it is difficult to determine whether the increased number of reports equates to an increasing rate in the emergence of these novel pathogens. It could simply mean that 
the increase in reports of novel pathogens is due to the growing affordability of, and improvements in, whole genome sequencing technologies and molecular diagnostics that enable rapid and accurate identification of emerging clones. However, increasing emergence of novel strains is also likely- given the rapid rise in human population, increased demands on food production and the speed by which people and commodities move globally. Either way, the suite of acquired resistance genes these novel pathogens harbor clearly indicates the significant role played by Lateral Gene Transfer (LGT) in shaping these genomes. Antibiotic resistance genes have a propensity to cluster on mobile elements and consequently a single LGT event can result in resistance to multiple antibiotic classes (Toleman and Walsh, 2011). Notably also, these trends are not restricted to Gram-negative pathogens but apply additionally to Gram-positive genomes.

Antibiotic resistance existed in nature long before the discovery of antibiotics 70 years ago. For example, genes encoding resistance to $\beta$-lactam(s), tetracycline and glycopeptide antibiotics have been identified from ancient metagenomic samples of 30,000 years old Beringian permafrost sediments (D'Costa et al., 2011). Controlling the spread of antibiotic resistance into diverse pathogens, and particularly multidrug resistance, requires better use of currently available antibiotics. It is insufficient to rely on the development of new antibiotics or antibiotic adjuncts. More effective use of existing antibiotics can be guided by molecular surveillance of microbiomes.

It is now clear that multiple distinct antibiotic resistance genes forming complex resistance gene loci (CRL) in MDR bacterial genomes were likely acquired from disparate backgrounds. Many MDR bacteria resulting in hospital infections carry genes encoding resistance to antibiotics used frequently in food animal production or resistance genes that have been acquired from aquatic and soil environments (Szczepanowski et al., 2009; Popowska and Krawczyk-Balska, 2013; Wibberg et al., 2013). This is not surprising given that New Generation DNA sequencing has revealed a vast repertoire of drug resistance determinants across diverse microbiomes (Forsberg et al., 2012). It has, however, largely gone unnoticed, because of the way in which molecular surveillance is carried out differentially in hospital and veterinary microbiology laboratories.

Screening procedures in hospital and veterinary laboratories are quite justifiably influenced by the urgent need to deal with an infectious threat; thus screening is carried out on the basis of resistance to the set of antibiotics that are of relevance to the respective unit. This means, for example, that although mercury resistance transposons are one of the largest carriers of multiple antibiotic resistance genes, veterinary and clinical hospital microbiology laboratories do not screen for mercury resistance. Focused surveillance approaches have thus resulted in an underestimated view of the real problem of antibiotic resistance. In recognition of the importance of fully understanding the problem of antibiotic resistance, recent $\mathrm{WHO}$ and $\mathrm{UK}$ government reports have advocated a "one health" approach that uses genomic surveillance of both clinical and food animal isolates (Department of Heath and Department for Environment Food and Rural Affairs, 2013; WHO, 2014).
The disparate reservoirs of drug resistance determinants raises important questions regarding the extent of transmissibility of the pool of resistance genes and the range of bacteria that can acquire them as a consequence of LGT. This review will give an overview of antibiotic resistance gene reservoirs with particular focus on the reservoirs in food animals, soil and water resulting from the in-feed use of large quantities of sub-therapeutic doses of antibiotics as growth promoting agents in food animal husbandry. It will highlight a significant gap in our knowledge regarding the evolution of MDR in bacteria: the range of factors that trigger the selection and mobilization of antibiotic-resistance genes from environmental reservoirs into clinically-relevant organisms. The complexity of the evolution of MDR in bacteria has myriad implications, including, for example, for the choice of alternative food animal growth promoters other than in-feed antibiotics. This review will point to considerations relevant to this choice.

\section{AN ASSESSMENT OF THE REPERTOIRE OF RESISTANCE GENES AND EFFECTS OF LOW DOSE ANTIBIOTICS ANTIBIOTIC RESISTANCE GENES PRESENT IN DISPARATE RESERVOIRS}

The antibiotic resistance genes that accumulate in the genomes of bacteria are likely to have their origins in disparate reservoirs, a conclusion arrived at in several independent recent studies on the evolution of MDR (Aminov, 2011; Amos et al., 2014; Guerra et al., 2014; Hsu et al., 2014; Ojer-Usoz et al., 2014) and evidenced also by the widespread dissemination of various antibiotic resistance genes, including those encoding resistance to extended spectrum $\beta$-lactamases in birds and other wildlife species (Costa et al., 2008; Poeta et al., 2008; Simoes et al., 2010). Aquatic and soil environments serve as sinks of older generation antibiotics including sulphonamides, tetracycline, amoxicillin, ampicillin and trimethoprim (Boxall, 2004; Monteiro and Boxall, 2009). The pools of antibiotic resistance genes available for dissemination (known as the "resistome") are enriched by veterinary and agricultural practices, human sewage and hospital waste (Tennstedt et al., 2005; Galvin et al., 2010; Heuer et al., 2011; Wellington et al., 2013; Hsu et al., 2014; Ojer-Usoz et al., 2014).

Genes imparting antibiotic resistance move within bacterial population(s) through LGT, independent of the linear "parent to progeny" descent (Tennstedt et al., 2005; Stokes and Gillings, 2011). The genes can be from a wide "gene pool" and can be transmitted between closely and distantly related species. Examples in which LGT plays a significant role in the evolution of important multi-resistant pathogenic bacterial genomes include, but are not restricted to, E. coli, Pseudomonas aeruginosa, and Vibrio cholerae. Notably, these organisms can survive in a range of environmental niches outside of the human body, including fomites in hospitals, soil and aquatic environments. Consequently, there exists diverse niche-adapted pools of microbial communities that can provide opportunities for the sampling and exchange of genetic information. Further, these opportunities are likely to be influenced significantly by the ecology of the niche-adapted microbial communities (Heuer et al., 2009, 2011; Galvin et al., 2010; Forsberg et al., 2012; Wellington et al., 2013). 


\section{FOOD ANIMALS, SOIL, AND WATER ARE IMPORTANT RESERVOIRS OF ANTIBIOTIC RESISTANCE GENES}

Reservoirs of antibiotic resistance genes that are increasingly recognized as important are the gastrointestinal tract of food animals, soil and water. This is because of the practice of using sub-therapeutic doses of antibiotics to promote the growth of food animals and the prophylactic use of antibiotics to prevent disease in food animals. A significant percentage of administered antibiotics are excreted in animal waste. Un-metabolized antibiotics concentrate in animal waste ponds and, depending on their chemical composition, partition to different fractions during the wastewater treatment processes (Kolpin et al., 2002; Ghosh and Lapara, 2007; Watanabe et al., 2010; Cheng et al., 2013; Li et al., 2013). Thus, antibiotics enter into environments/ecosystems where bacteria pathogenic to humans may also survive (Sarmah et al., 2006). The antibiotics used with food animals for growth promotion and prophylactically include a set of FDA (FDA, 2011) approved drugs, recognized by the World Health Organization as important to treat human diseases (Table 1) (Aarestrup et al., 2008). Further, the quantities of antibiotics administered to food animals are very large. In Australia, in the period 2005 to $2010,98 \%$ of veterinary antibiotics sold were for use in food animals. Only approximately $43 \%$ were sold for therapeutic or prophylactic purposes (no distinction could be drawn between "therapeutic" and "prophylactic" uses as it was difficult for those surveyed to estimate the proportions of products used for these purposes). This means that, on average, for the surveyed period, sales of antimicrobials for growth promotion averaged 35.3 tons; in 2005-2006 this was as much as 47.2 tons (APVMA, 2014). Importantly, a large proportion of the antimicrobials sold (almost 77\%), were administered in feed.

The practice of using sub-therapeutic doses of antibiotics to promote growth of food animals became widespread following initial studies of the effect of antibiotics on the growth of broiler chickens (Elam et al., 1953; Jacobs et al., 1953; Izat et al., 1990; Dibner and Richards, 2005; Castanon, 2007). Antibiotics are used for growth promotion in doses lower than the recommended minimum effective concentrations (MEC) for therapeutic purposes but often at concentrations greater than the minimum inhibitory concentration (MIC) of specific drug/microbe combinations (Berrang et al., 2007; Alexander et al., 2008; Mirzaagha et al., 2011; Holman and Chenier, 2013). The practice of using antibiotics to promote growth of food animals has been banned in several countries in Europe due to concerns over the development and spread of antimicrobial resistance (Gilbert, 2011; Maron et al., 2013).

\section{IMPACT OF SUB-INHIBITORY CONCENTRATIONS OF ANTIBIOTICS ON BACTERIA}

The practice raises concerns over the development and spread of antimicrobial resistance because sub-inhibitory concentrations of antibiotics can enhance LGT (Barr et al., 1986; Torres et al., 1991; Stevens et al., 1993); potentially act as signal transduction molecules (Romero et al., 2011) in the transition from planktonic to biofilm phase during the process of monomicrobial and polymicrobial biofilm formations,(Bagge et al., 2004; Hoffman et al., 2005); and globally modulate transcriptional activity. Subtherapeutic doses of $\beta$-lactam antibiotics has been shown to enhance the rate of conjugative plasmid transfer (Barr et al., 1986) and tetracycline has been implicated in driving the lateral transfer of integrative conjugative elements (Torres et al., 1991; Stevens et al., 1993). Conjugative transfer of single-stranded (ss) DNA (the mechanism by which plasmids are transferred from donor to recipient cells) induces the bacterial SOS response, which in turn up-regulates expression of the integron integrase resulting in the capture or exchange of resistance genes in Gram-negative pathogens (Baharoglu et al., 2010). Integron-mediated gene shuffling events in $V$. cholerae and $E$. coli were elevated significantly (4.5-fold and 37-fold increase respectively) in response to antibiotic mediated stress, which in turn triggered the SOS response. In addition, the study also reported up-regulation of the frequency of integron-associated excision/shuffling of gene-cassettes by 141 -fold in $V$. cholera and 340-fold in E. coli, in a SOS response mediated event. In a recent study, Zhu et al. (2013) demonstrated the presence and relative abundance (an increase of 198-fold on average) of 149 antibiotic resistance genes (of 244 included in the study) conferring resistance to common in-feed and veterinary antibiotics used in the swine farming industry in China within 36 metagenomic samples extracted from compost, manure and soil. The study also provided evidence of abundance and enrichment of common transposase genes [identified in the course of a previous study (Aziz et al., 2010)] known to be frequently associated with antibiotic resistance genes. The conclusions of the study included a statement of the likely roles played by the subset of mobile elements in LGT of resistance genes in China (Zhu et al., 2013).

In a pioneering transcriptome analyses study, Goh et al. provided direct evidence of the global modulation of transcriptional activity of genes in Salmonella enterica serovar Typhimurium in the presence of sub-inhibitory concentrations of antibiotics like erythromycin (used as Antimicrobial growth promoters or AGP for poultry and swine) and rifampicin (Goh et al., 2002). Further gene-expression studies have now presented data on the influence of sub-inhibitory concentrations of antibiotics on the global transcriptome of genes related to virulence (Subrt et al., 2011), colonization (Bagge et al., 2004), motility, SOS stress response (inducible DNA repair system) and biofilm formation (Kaplan et al., 2012) for many important human pathogens (Davies et al., 2006). Notably, stress responses have been shown to enhance bacterial adaptation through increased mutation and LGT (Aertsen and Michiels, 2006; Baharoglu and Mazel, 2011).

\section{LGT OF RESISTANCE GENES AND CO-SELECTION OF OTHER RESISTANCE DETERMINANTS BY THE FORMATION OF COMPLEX RESISTANCE LOCI COMPLEX RESISTANCE GENE LOCI-MULTIPLE ANTIBIOTIC RESISTANCE GENES AND MOBILE ELEMENTS}

Genes that encode resistance to antibiotics often appear clustered in the genomes of many bacteria, forming CRL (Parkhill et al., 2001; Szczepanowski et al., 2005, 2009; Tennstedt et al., 2005; Roy Chowdhury et al., 2009, 2011; Venturini et al., 2010; Toleman and Walsh, 2011). In addition to antibiotic resistance genes, the CRL possess diverse mobile genetic elements (predominantly insertion 
Table 1 | List of FDA approved Antibiotic classes and countries still using them in growth promotion, associated resistance genes and genetic scaffolds that laterally co-mobilize them with other antibiotic and metal resistance genes.

\begin{tabular}{|c|c|c|c|c|}
\hline $\begin{array}{l}\text { Antibiotic classes: } \\
\text { specific examples }\end{array}$ & $\begin{array}{l}\text { Countries still using } \\
\text { them }\end{array}$ & $\begin{array}{l}\text { Associated resistance } \\
\text { genes }\end{array}$ & $\begin{array}{l}\text { Association of genes with } \\
\text { mobile elements }\end{array}$ & $\begin{array}{l}\text { Examples of } \\
\text { co-resistances }\end{array}$ \\
\hline \multirow[t]{2}{*}{$\begin{array}{l}\text { Penicillins: amoxicillin, } \\
\text { ampicillin }\end{array}$} & $\begin{array}{l}\text { United States (Mathers } \\
\text { et al., 2011), Sudan } \\
\text { (Eltayb et al., 2012) }\end{array}$ & blaTEM genes & $\begin{array}{l}\text { blaTEM genes transposons } \\
\text { (Bailey et al., 2011) and } \\
\text { plasmids (Cain et al., 2010) }\end{array}$ & $\begin{array}{l}\text { Lead, cadmium, zinc and } \\
\text { chromium (Yamina et al., } \\
\text { 2012) }\end{array}$ \\
\hline & & & & $\begin{array}{l}\text { mer genes; mercury } \\
\text { (Mcintosh et al., 2008) }\end{array}$ \\
\hline
\end{tabular}

\begin{tabular}{|c|c|c|c|c|}
\hline $\begin{array}{l}\text { Glycopeptides: avoparcin, } \\
\text { vancomycin }\end{array}$ & $\begin{array}{l}\text { Mexico (Maron et al., } \\
\text { 2013) }\end{array}$ & van genes & $\begin{array}{l}\text { van genes [transposons } \\
\text { (Jensen et al., 1999; Leavis } \\
\text { et al., 2003) and plasmids } \\
\text { (Zhu et al., 2010, 2013)] }\end{array}$ & $\begin{array}{l}\text { tcrB gene; copper (Hasman } \\
\text { and Aarestrup, 2002) }\end{array}$ \\
\hline
\end{tabular}

\begin{tabular}{|c|c|c|c|c|}
\hline $\begin{array}{l}\text { Macrolides: } \\
\text { erythromycin, tylosin, } \\
\text { tilmicosin, kitasamycin, } \\
\text { oleandomycin }\end{array}$ & $\begin{array}{l}\text { United States (Kim et al., } \\
\text { 2012), Australia (Hughes } \\
\text { and Heritage, 2004), } \\
\text { Mexico (Maron et al., } \\
\text { 2013) }\end{array}$ & $\begin{array}{l}\text { erm gene cluster } \\
\text { CmeABC multi-drug } \\
\text { efflux pump (Lin et al., } \\
\text { 2007) }\end{array}$ & $\begin{array}{l}\text { erm gene cluster } \\
\text { [transposons (Li et al., 2011; } \\
\text { Ramos et al., 2012) and } \\
\text { plasmids (Wendlandt et al., } \\
\text { 2014)] }\end{array}$ & $\begin{array}{l}\text { erm genes; tetracycline and } \\
\text { streptogramin (Ramos } \\
\text { et al., 2012) } \\
\text { tcrB gene; copper (Hasman } \\
\text { and Aarestrup, 2002) }\end{array}$ \\
\hline $\begin{array}{l}\text { Streptogramins: } \\
\text { virginiamycin, } \\
\text { quinupristin-dalfopristin }\end{array}$ & $\begin{array}{l}\text { United States (Kieke } \\
\text { et al., 2006), Australia } \\
\text { (Hughes and Heritage, } \\
\text { 2004), Mexico (Maron } \\
\text { et al., 2013) }\end{array}$ & $\begin{array}{l}\text { vatD and vatE } \\
\text { erm gene cluster } \\
\text { satA (Hammerum et al., } \\
\text { 1998) } \\
\text { varS (Lee et al., 1999; } \\
\text { Kieke et al., 2006) }\end{array}$ & $\begin{array}{l}\text { vatD and vatE plasmids } \\
\text { (Allignet and El Solh, 1999) } \\
\text { erm gene cluster } \\
\text { [transposons (Li et al., 2011; } \\
\text { Ramos et al., 2012) and } \\
\text { plasmids (Wendlandt et al., } \\
\text { 2014)] }\end{array}$ & $\begin{array}{l}\text { erm genes; macrolide and } \\
\text { tetracycline (Ramos et al., } \\
\text { 2012) }\end{array}$ \\
\hline
\end{tabular}

\begin{tabular}{|c|c|c|c|c|}
\hline $\begin{array}{l}\text { Sulfonamides: } \\
\text { sulfisoxazole, } \\
\text { sulfadimethoxine, } \\
\text { sulfamethazine }\end{array}$ & $\begin{array}{l}\text { Sudan (Eltayb et al., } \\
\text { 2012), United States } \\
\text { (APUA, 2010) }\end{array}$ & sul genes & $\begin{array}{l}\text { sul genes [transposons } \\
\text { (Cain et al., 2010), plasmids } \\
\text { (Wu et al., 2010) and clinical } \\
\text { class } 1 \text { integrons (Stokes } \\
\text { and Hall, 1989; Wu et al., } \\
\text { 2010)] }\end{array}$ & $\begin{array}{l}\text { czcA gene; zinc, cadmium } \\
\text { and cobalt (Stokes et al., } \\
\text { 2006; Gillings et al., 2008) } \\
\text { mer genes; mercury } \\
\text { (Mcintosh et al., 2008) }\end{array}$ \\
\hline $\begin{array}{l}\text { Tetracyclines: } \\
\text { chlortetracycline, } \\
\text { oxytetracycline, } \\
\text { doxycycline }\end{array}$ & $\begin{array}{l}\text { United States (Cox and } \\
\text { Popken, 2010; Mathers } \\
\text { et al., 2011), China (Wu } \\
\text { et al., 2010), Sudan } \\
\text { (Eltayb et al., 2012) }\end{array}$ & tet genes & $\begin{array}{l}\text { tet genes [transposons } \\
\text { (Schmitt et al., 1979; Ramos } \\
\text { et al., 2012) and plasmids } \\
\text { (Han et al., 2012; Wendlandt } \\
\text { et al., 2014)] }\end{array}$ & $\begin{array}{l}\text { erm genes; macrolide and } \\
\text { streptogramin (Ramos } \\
\text { et al., 2012) } \\
\text { mer genes; mercury } \\
\text { (Mcintosh et al., 2008) }\end{array}$ \\
\hline Polypeptides: bacitracin & $\begin{array}{l}\text { Mexico (Maron et al., } \\
\text { 2013) }\end{array}$ & $\begin{array}{l}\text { rgpA-F, mbrA-D (Tsuda } \\
\text { et al., 2002) } \\
\text { bcr }\end{array}$ & $\begin{array}{l}\text { bcr [plasmids (Tremblay and } \\
\text { Archambault, 2013)] }\end{array}$ & \\
\hline $\begin{array}{l}\text { Amphenicols: } \\
\text { chloramphenicol }\end{array}$ & China (Li et al., 2013) & $\begin{array}{l}\text { cmlA } \\
\text { floR } \\
\text { fexA and fexB } \\
\text { cfr } \\
\text { cat gene }\end{array}$ & $\begin{array}{l}\text { cat gene [transposons, } \\
\text { (Cain and Hall, 2012), } \\
\text { plasmids (Mcintosh et al., } \\
\text { 2008) and integrons (Bunny } \\
\text { et al., 1995)] }\end{array}$ & $\begin{array}{l}\text { mer genes; mercury } \\
\text { (Mcintosh et al., 2008) }\end{array}$ \\
\hline
\end{tabular}

elements, transposons and integrons) clustered either in independently replicating units, like plasmids, or in genomic islands within the bacterial chromosome. Mobile elements facilitate dissemination of CRL within bacteria. Acquisition of a CRL by any bacterium thus provides a survival mechanism to it when exposed to an entire range of antimicrobial agents. CRL evolve rapidly, especially within Gram-negative bacteria, and they generally contain hotspots where additional resistance genes can accumulate.
Lateral transfer of genes within the gastrointestinal tracts of humans and food animals, and in reservoirs where environmental bacteria mix with bacteria derived from anthropogenic activities (sewage, hospital waste and food production animal waste) significantly contribute to these evolutionary processes (Forsberg et al., 2012). Although mobile genetic elements are a key component of CRL, there is currently limited understanding of the different types of mobile genetic element(s) that may contribute to: (1) 
the spread of CRL; (2) the diversity of resistance gene reservoirs that can be utilized by the mobile elements to form CRL and (3) the mechanisms by which resistance genes assemble on laterally mobile segments of DNA.

\section{INTEGRONS ARE MOBILE ELEMENTS ASSOCIATED WITH CRL AND FOUND IN DIVERSE BACTERIA}

Integrons represent a group of genetic elements that are most commonly found in association with CRL and have been implicated in the rapid evolution of multi-drug resistance within Gram-negative pathogens (Martinez et al., 2013). Based on the amino acid sequences of the integrase/recombinase gene intI (Recchia and Hall, 1995) integrons can be differentiated into several classes, all of which are found in diverse microbial communities (Marquez et al., 2008). Classes 1-3 are most frequently associated with the dissemination of MDR within Gram-negative bacteria, although recently class 1 integrons have also been identified in Gram-positive bacteria (Nandi et al., 2004; Shi et al., 2006; Xu et al., 2010, 2011). Exchange of resistance genes within different classes of integrons (from diverse bacteria) has been reported in a range of microbial communities (Labbate et al., 2008; Roy Chowdhury et al., 2009). The role of class 1 integrons in the evolution of MDR within hospitals is most comprehensively documented (Djordjevic et al., 2013; Martinez et al., 2013), although they are also frequently reported from environmental bacteria (Holmes et al., 2003; Stokes et al., 2006). Functionally, a class 1 integron is a two-component site-specific gene recombination system. Structurally a class 1 integron comprises an integrase gene and a tandem array of a variable number of independently acquired mobile genes. The independently mobile units of a class 1 integron are called "gene cassettes" and are made up of a promoter-less open reading frame and a recombination site. Class 1 integrons most frequently contain multiple gene cassettes, in structures called "cassette arrays," that can be expressed from a single promoter (Stokes and Hall, 1989) in an operon-like manner. Exchange/insertion/deletion of gene cassettes (by the process of site-specific recombination) and expression of these genes enables their host to exhibit multiple "acquired" resistance phenotypes simultaneously and relatively quickly (on an evolutionary time scale).

A key component of the integron integrase is the integrase promoter $\left(\mathrm{P}_{\text {int }}\right)$ (Stokes and Hall, 1989). The regulation and expression of the integron integrase is an adaptive response to stress, including that induced by sub-lethal dosages of antibiotics in any environment (Guerin et al., 2009). Hocquet et al. described a metronidazole induced cassette rearrangement in a class 1 integron that resulted in the formation of a fused $g c u F 1-b l a_{\mathrm{OXA}-28}$ cassette, which subsequently led to the expression of the fused $\beta$-lactamase gene and ceftazidime resistance in a P. aeruginosa isolate (Hocquet et al., 2012). A LexA binding site is found conserved across the vast majority of integrase genes, indicating the likelihood of bacterial SOS mediated up-regulation of most integron integrases (Guerin et al., 2009). Importance of the LexA binding site has been experimentally demonstrated in Vibrio spp. and E. coli (Guerin et al., 2009).

Class 1 integrons isolated from clinical samples, are predominantly linked to the Tn 3 family of transposons, particularly $\operatorname{Tn} 21$
(Liebert et al., 1999) and Tn1696 (Partridge et al., 2001), which in turn harbor clustered mercury resistance genes. Class 1 integrons also have a propensity of targeting resolution sites of plasmids or other transposons on plasmid backbones (Kholodii et al., 1995; Minakhina et al., 1999). Thus, in addition to carrying genes conferring MDR, class 1 integrons also associate with other mobile elements, which independently carry other combinations of resistance genes to form laterally mobile resistance scaffolds (Parkhill et al., 2001; Szczepanowski et al., 2005; Tennstedt et al., 2005; Wibberg et al., 2013).

\section{CO-SELECTION AND TRANSFER OF ANTIBIOTIC AND OTHER RESISTANCE GENES - THE ROLE OF PLASMIDS}

Plasmids play a central role in the lateral transfer of CRL within both closely and distantly related Gram-negative bacteria. Identical CRL are frequently seen piggy-backing on different plasmid backbones isolated from different hosts, supporting the role of plasmids in the transfer of drug resistance loci. Such events are best exemplified by plasmids carrying identical complex Tn21associated MDR regions (Tennstedt et al., 2005; Szczepanowski et al., 2009; Venturini et al., 2013). Recent examples of such plasmids with complex resistance loci isolated from waste water treatment plants include IncF plasmids pRSB225 (Wibberg et al., 2013) and pRSB107 (Szczepanowski et al., 2005) and the series of IncP-1 plasmids reviewed recently by Popowska and KrawczykBalska (2013). Although isolated from waste water treatment plants, all these plasmids and a set of 140 plasmids described in a recent plasmid metagenomic study by Szczepanowski et al. clearly indicate that the resistance gene pool within the CRL on the plasmids are an admixture of genes that have originated from different bacterial communities (Szczepanowski et al., 2009).

The co-selection of antibiotic resistance genes by plasmids containing transposons with genes encoding resistance to heavy metals (such as mercury, cadmium, copper, and zinc) adds to the complexity of the evolution of laterally mobile clustered resistance regions (Seiler and Berendonk, 2012). This is particularly so when considering food animals and their environments (e.g. soil and water) as reservoirs of antibiotic resistance determinants; metals like copper and zinc, all of which are often used in animal husbandry for growth promotion (Jacob et al., 2010). This phenomenon of co-selection of resistance genes on plasmids increase the opportunity for microbial populations, that proliferate both in the gastrointestinal tracts of mammals and that survive in soil and aquatic environments, to act as major conduits in the flow of resistance genes between these reservoirs.

Plasmids pO26-CRL, pO26- $\mathrm{CRL}_{125}$ (isolated from an enterohemorrhagic E. coli specimen from a human with bloody diarrhea) and pO111-CRL $L_{115}$ (isolated from a bovine source in Australia) are examples of plasmids with identical clustered antibiotic and metal resistance genes that have been identified recently by our group (Venturini et al., 2010, 2013). The CRL in these plasmids are characterized by a Tn21-associated class 1 integron truncated by the presence of a composite IS 26 transposon, Tn6026 (Cain et al., 2010). Composite transposons, another type of mobile element frequently associated with CRL, are defined as segments of DNA bounded by two related insertion elements (or IS elements). DNA segments between two IS elements mobilize 
intervening genes as a single unit. Composite transposons therefore have the ability to capture and mobilize random pieces of DNA from many diverse genetic locations, promoting genetic diversity. In relation to evolution of MDR, composite transposons can allow the movement of clustered antibiotic resistance genes from one bacterial genome to another through the capture of such genes into bacteriophages or conjugative plasmids that can then move readily between bacteria. Tn6026 is an example of a composite transposon, which consists of two independently mobile composite transposons, Tn6029 and Tn4352 (Cain et al., 2010; Martinez et al., 2013). Collectively the CRL (described above as Tn6026) confers resistance to ampicillin, kanamycin, neomycin, streptomycin, sulfathiazole and trimethoprim. Similar structures, consisting of Tn6029 derivatives and essentially consisting of the same group of resistance genes have been described in plasmids such as pASL01a, which circulates in commensal E. coli in the human population in West Africa (Labar et al., 2012), and pHCM1, from a human E. coli isolate from a patient living in the Mekong Delta in Vietnam (Parkhill et al., 2001). However, the group of plasmids described by us, pO26-CRL, pO26-CRL ${ }_{125}$, and pO111-CRL $L_{115}$, is a clear example of plasmid mediated LGT of CRL between animal and human reservoirs in recent times.

IncA/C plasmids can provide conjugative functions in trans to mobilize integrative elements such as Salmonella Genomic Island 1 (SGI1) (Douard et al., 2010). SGI1 harbors genes encoding resistance to seven antibiotics (ampicillin, chloramphenicol, florphenicol, streptomycin, spectinomycin, tetracycline and sulphonamides). The resistance genes are clustered on a $13-\mathrm{kb}$ class 1 integron, In104, embedded within a 42.4-kb genomic island embedded between thdF and yidY genes (Boyd et al., 2001; Levings et al., 2005). SGI1 is widely dispersed among a range of S. enterica serovars and Proteus mirabilus (Levings et al., 2005, 2006, 2007; Djordjevic et al., 2009; Le Hello et al., 2011, 2012), clearly indicating the lateral transfer of the element within bacteria occupying disparate hosts. A structurally similar CRL is also found in SGI2 described initially from a S. enterica serovar Emek strain in Australia. Major differences between SGI1 and SGI2 are in the physical location of the class 1 integron on the genomic backbone and in the different set of resistance gene cassettes seen associated with the integron found in SGI2. The integron, known as InEmek is a close variant of In104 seen in SGI1 (Levings et al., 2008) and the entire island shows characteristic features that mobilize SGI1.

\section{NOVEL STRATEGIES AND ALTERNATIVES TO IN-FEED ANTIBIOTICS}

The growing knowledge of how LGT drives the evolution of MDR in bacteria and the importance of disparate pools of resistance genes has implications for the use of antibiotics as growth promoters in food animals, suggesting a need for novel alternatives to in-feed antibiotics. These alternatives should, in development, pay regard to: (1) the potential dangers for increasing evolution of MDR in bacteria when altering the microbial ecology of the gut (as most currently used growth promoters appear to do) (Dibner and Richards, 2005); and (2) consideration of questioning the effectiveness of in-feed antibiotics as growth promoters (Bengtsson and Wierup, 2006). Kim et al. conducted a comparative fecal microbiome study on two separate porcine populations, one of which was given a diet supplemented with the macrolide tylosin (a commonly used AGP), while the other group represented the control (Kim et al., 2012), i.e., did not receive tylosin, and reported the flux of microbial communities within them over a period of time. The fecal microbiome of each group was determined, which initially showed a prominent shift in microbial content for all species detected, proving that AGPs such as tylosin alter the native intestinal flora, resulting in less competition for nutrients and ultimately leading to the desired growth promoting effects. However, this study also showed that fecal microbiomes from the control group eventually became indistinguishable to those of the tylosin-fed group, offering an air of redundancy to the use of AGPs with respect to health and welfare of the animals. An important aspect of this study was that it was conducted in two separate farm settings, instead of the common choice among similar studies of an infectious disease isolation facility, making the results more comparable and applicable to the pig-farming industry.

Any alternative strategy for growth promotion in food animals over antibiotics needs to consider the growing understanding of the triggers for lateral transfer of CRL and the warning provided by evidenced movement of CRL between disparate bacterial hosts as consequences of administration of sub-inhibitory dosages of antibiotics. Controlling the spread of antibiotic resistance is not so simple as banning non-therapeutic in-feed antibiotics and using anything else as a growth promoter. This is clearly demonstrated by the problems associated with the use of heavy metals as growth promoters in relation to lateral co-transfer of associated antibiotic resistance genes. Further, an ideal alternative to in-feed AGPs should ideally meet the definition for feed additives set by The Official Journal of the European Union (Council Directive 89/107/EEC). The derivative clearly states "any substance not normally consumed as a food in itself and not normally used as a characteristic ingredient of food whether or not it has nutritive value, the intentional addition of which to food for a technological purpose in the manufacture, processing, preparation, treatment, packaging, transport or storage of such food results, or may be reasonably expected to result, in it or its byproducts becoming directly or indirectly a component of such foods" (Council Directive 89/107/EEC). With respect to farming and animal husbandry, the novel additive should ideally improve the characteristics of the feed itself as well as dairy and deli products derived from the receiving animal. They should increase the efficiency of animal performance and welfare via the gastrointestinal microbiota and satisfy the nutritional requirements of the animal. Additionally, the additive should not adversely impact the environment or human/animal health. From this perspective, it is questionable whether the environmental accumulation of minerals, such as zinc oxide (often used as an alternative to in-feed antibiotics), is worth the positive effects of growth promotion and prophylaxis for conditions such as E. coli mediated post-weaning diarrhea in piglets (Pluske, 2013).

A diverse range of options, which could possibly minimize or ideally alleviate forces that drive lateral transfer of resistance genes within the gut microbiome, have been proposed as alternatives of AGPs including, but not limited to, enzymes, nutraceuticals, 
amino acids and plant extracts (Askbrant et al., 1994; Hill et al., 2000; Barrerra et al., 2004; Schone et al., 2006; Muhl and Liebert, 2007; Nortey et al., 2007; Ragland et al., 2007; Jacela et al., 2008). These have shown varying outcomes in the promotion of growth in different animals (Supplementary Table 1). Therefore, it is most likely that a combination of these substitutes may serve as a better alternative that could account for all benefits and functions of in-feed antibiotics than any individual substance tested for the purpose. This idea was investigated within poultry by Ohimain and Ofongo (2012). They reported the effects of using a mixture of probiotics, prebiotics and enzymes as a dietary supplement in poultry. The probiotics and prebiotics had a synergistic effect, while the enzymes enhanced digestibility of the feed, increasing the amount of nutrients available for absorption. The combined effect improved digestive health in the chickens and consequently protected them against common microbial diseases such as enteritis (Ohimain and Ofongo, 2012). Probiotics, on the other hand, have been documented to prevent inflammation in the gut, reduce the incidence of meat contamination and promote growth, proving a propitious alternative to AGPs (Patterson and Burkholder, 2003). Use of non-pathogenic E. coli probiotics in combination with a low-protein diet in a porcine model was shown to reduce mucosal populations of pathogenic E. coli K88, subsequently decreasing the incidence of post-weaning diarrhea. These effects were attributed to the production of colicin by some bacteria introduced via the probiotic product (Bhandari et al., 2010) as well as the unavailability of protein normally utilized by the pathogenic E. coli for energy production. A similar study used a low-protein diet with the addition of essential amino acids (Heo et al., 2008) and described similar results. Further development of such strategies would assist in controlling the spread of antibiotic resistance, as well as reduce appearance of medical conditions such as post-weaning diarrhea in piglets, a major cause of economic hardship in swine production (Pluske, 2013).

One of the main problems of developing alternatives to infeed AGPs is that the mechanism of action of AGPs is still largely unknown. No general consensus for the mechanism of action of AGP exists, however, several hypotheses have been proposed and evaluated, including: (1) reduction in total bacterial load as a consequence of administrated antibiotics; (2) reduction in the number of pathogenic bacteria resulting in better animal health; and (3) manipulation of the gut microflora in a way that natural immune and metabolic responses balance resulting in healthy animals (Dibner and Richards, 2005). Like existing alternatives to in-feed antibiotics, proposed novel alternatives tend to have a mechanism of action which directly affects the composition and quantity of bacteria within the animal's gastrointestinal system, suggesting a link between commensal bacteria and growth performance. The effects of AGP on porcine and broiler chicken intestinal microbiomes have been reported (Collier et al., 2003; Dumonceaux et al., 2006), as well as the positive effects of the change in composition of these microbiomes in response to infeed antibiotics. These studies mirror those reported by Kim et al., as well as provide evidence to the hypothesis of this mode of action. Collier et al. and Dumonceaux et al. also identified bacterial composition within specific regions of the gastro-intestinal tract, and in doing so created a link between the alterations of bacterial communities most affected by the antibiotics and areas of the intestine most involved in nutrient absorption.

Several reports have linked the use of AGPs (Feighner and Dashkevicz, 1987; Knarreborg et al., 2004; Guban et al., 2006) to the reduction in activity of intestinal bile salt hydrolase (BSH). This enzyme directly affects lipid metabolism within the host and is produced by bacteria that occur naturally in the gut. The observation led to a new avenue of research into factors that target bacterial products rather than the bacteria themselves. Based strictly on an in vitro study, Wang et al. (2012) proposed the use of bile salt inhibitors as growth performance enhancers (Wang et al., 2012). Whether BSH inhibitors would adequately function in an in vivo model is still unclear. Zinc and copper, (common feed additives for increasing feed efficiency and promoting growth), were shown to cause inhibition of BSH and improve lipid metabolism. There are likely to be a number of non-metal BSH inhibitors, so this research path, with further studies into non-environmentally contaminating compounds, is a promising replacement for in-feed antibiotics.

\section{CONCLUDING REMARKS}

Laterally acquired DNA is a major driver of genome plasticity and poses problems for the reliable identification and classification of emerging pathogens, a necessary pre-requisite for using molecular surveillance as a tool for guiding effective use of existing antibiotics. For many years microbiological and molecular epidemiological surveillance studies within the veterinary and hospital environments have focused on characterizing their own targeted bacteria and antibiotic resistance profiles rather than taking a larger "one health" view of microbial resistance. Consequently, the molecular structures and CRL scaffolds that laterally mobilize drug resistance determinants between communities have been relatively under-studied. The sequences of plasmids; transposons; integrons insertion elements; genomic islands and other mobile elements need to be comprehended fully to unravel the real complexity of the problem. MDR evolves where antibiotics are used heavily, irrespective of whether it is in human clinical environments, food animal production settings, aquaculture or horticulture. Genetic phenomena like LGT inextricably links genes from disparate reservoirs to form CRL. These concepts, although increasingly recognized by the scientific community are not clearly communicated to the general public. Raised awareness of the complexity and far reaching implications associated with antibiotic resistance and a "one health" approach are critical for a global, sustained effort needed to alleviate the serious threat posed by multiple antibiotic resistant infectious agents. Molecular surveillance strategies embracing a "one health" approach are expected to provide a better understanding of how the genes flow through microbial communities and therefore provide a platform to more accurately predict and contain imminent threats posed by MDR bacteria.

One of the major challenges going forward is to stem the use of antibiotics and seek effective alternatives in our food production industries because antibiotic resistance gene reservoirs associated with food animals contribute to the evolution of MDR bacteria. One starting point for this is the development of alternatives to in-feed AGPs. This development should include studies that 
incorporate a full range of animals within the farming industry, as intestinal microbiomes are likely to differ between species. It should further include new approaches to gauge the effects of probiotics and alternate in-feed growth promoters.

\section{SUPPLEMENTARY MATERIAL}

The Supplementary Material for this article can be found online at: http://www.frontiersin.org/journal/10.3389/fmicb. 2014.00394/abstract

\section{REFERENCES}

Aarestrup, F. M., Wegener, H. C., and Collignon, P. (2008). Resistance in bacteria of the food chain: epidemiology and control strategies. Expert Rev. Anti Infect. Ther. 6, 733-750. doi: 10.1586/14787210.6.5.733

Aertsen, A., and Michiels, C. W. (2006). Upstream of the SOS response: figure out the trigger. Trends Microbiol. 14, 421-423. doi: 10.1016/j.tim.2006.08.006

Ahmed, S. A., Awosika, J., Baldwin, C., Bishop-Lilly, K. A., Biswas, B., Broomall, S., et al. (2012). Genomic comparison of Escherichia coli O104:H4 isolates from 2009 and 2011 reveals plasmid, and prophage heterogeneity, including shiga toxin encoding phage stx2. PLoS ONE 7:e48228. doi: 10.1371/journal.pone. 0048228

Alexander, T. W., Yanke, L. J., Topp, E., Olson, M. E., Read, R. R., Morck, D. W., et al. (2008). Effect of subtherapeutic administration of antibiotics on the prevalence of antibiotic-resistant Escherichia coli bacteria in feedlot cattle. Appl. Environ. Microbiol. 74, 4405-4416. doi: 10.1128/AEM.00489-08

Allignet, J., and El Solh, N. (1999). Comparative analysis of staphylococcal plasmids carrying three streptogramin-resistance genes: vat-vgb-vga. Plasmid 42, 134-138. doi: 10.1006/plas.1999.1412

Aminov, R. I. (2011). Horizontal gene exchange in environmental microbiota. Front. Microbiol. 2:158. doi: 10.3389/fmicb.2011.00158

Amos, G. C., Zhang, L., Hawkey, P. M., Gaze, W. H., and Wellington, E. M. (2014). Functional metagenomic analysis reveals rivers are a reservoir for diverse antibiotic resistance genes. Vet. Microbiol. 171, 441-147. doi: 10.1016/j.vetmic.2014.02.017

Andersen, P. S., Stegger, M., Aziz, M., Contente-Cuomo, T., Gibbons, H. S., Keim, P., et al. (2013). Complete genome sequence of the epidemic and highly virulent CTX-M-15-producing H30-Rx subclone of Escherichia coli ST131. Genome Announc. 1:e00988-13. doi: 10.1128/genomeA.00988-13

APVMA. (2014). Quantity of Antimicrobial Products Sold For Veterinary Use in Australia July 2005 To June 2010. Licensed from the Australian Pesticides and Veterinary Medicines Authority (APVMA) under a Creative Commons Attribution 3.0 Australia Licence (ACT).

APUA. (2010). Public Health Consequences of Antibiotic Use For Growth Promotion. Policy Brief and Recommendations \#5. Misuse of Antibiotics in Food Animal Production.

Askbrant, S., Hakansson, J., Andersson, K., Svensson, C., and Malmlof, K. (1994). A short note on the effects of low-protein diets supplemented with biosynthetic amino acids on growing-finishing pig performance. Swed. J. Agric. Res. 24, 115-118.

Aziz, R. K., Breitbart, M., and Edwards, R. A. (2010). Transposases are the most abundant, most ubiquitous genes in nature. Nucleic Acids Res. 38, 4207-4217. doi: $10.1093 /$ nar/gkq140

Bagge, N., Schuster, M., Hentzer, M., Ciofu, O., Givskov, M., Greenberg, E. P., et al. (2004). Pseudomonas aeruginosa biofilms exposed to imipenem exhibit changes in global gene expression and beta-lactamase and alginate production. Antimicrob. Agents Chemother. 48, 1175-1187. doi: 10.1128/AAC.48.4.11751187.2004

Baharoglu, Z., Bikard, D., and Mazel, D. (2010). Conjugative DNA transfer induces the bacterial SOS response and promotes antibiotic resistance development through integron activation. PLoS Genet. 6:e1001165. doi: 10.1371/journal.pgen.1001165

Baharoglu, Z., and Mazel, D. (2011). Vibrio cholerae triggers SOS and mutagenesis in response to a wide range of antibiotics: a route towards multiresistance. Antimicrob. Agents Chemother. 55, 2438-2441. doi: 10.1128/AAC.01549-10

Bailey, J. K., Pinyon, J. L., Anantham, S., and Hall, R. M. (2011). Distribution of the blaTEM gene and blaTEM-containing transposons in commensal Escherichia coli. J. Antimicrob. Chemother. 66, 745-751. doi: 10.1093/jac/dkq529
Banerjee, R., and Johnson, J. R. (2013). Escherichia coli ST131: variations on a theme of clonal expansion. Enferm. Infecc. Microbiol. Clin. 31, 355-356. doi: 10.1016/j.eimc.2013.01.004

Barr, V., Barr, K., Millar, M. R., and Lacey, R. W. (1986). Beta-lactam antibiotics increase the frequency of plasmid transfer in Staphylococcus aureus. J. Antimicrob. Chemother. 17, 409-413. doi: 10.1093/jac/17.4.409

Barrerra, M., Cervantes, M., Sauer, W. C., Araiza, A. B., and Torrentera, N. (2004). Ileal amino acid digestibility and performance of growing pigs fed wheat-based diets. J. Anim. Sci. 82, 1997-2003.

Bengtsson, B., and Wierup, M. (2006). Antimicrobial resistance in Scandinavia after ban of antimicrobial growth promoters. Anim. Biotechnol. 17, 147-156. doi: 10.1080/10495390600956920

Berrang, M. E., Ladely, S. R., Meinersmann, R. J., and Fedorka-Cray, P. J. (2007). Subtherapeutic tylosin phosphate in broiler feed affects Campylobacter on carcasses during processing. Poult. Sci. 86, 1229-1233. doi: 10.1093/ps/86.6.1229

Bhandari, S. K., Opapeju, F. O., Krause, D. O., And Nyachoti, C. M. (2010). Dietary protein level and probiotic supplementaton effects on piglet response to Eschericia coli $\mathrm{K} 88$ challenge: performance and gut microbial population. Livest. Sci. 133, 185-188. doi: 10.1016/j.livsci.2010.06.060

Bielaszewska, M., Schiller, R., Lammers, L., Bauwens, A., Fruth, A., Middendorf, B., et al. (2014). Heteropathogenic virulence and phylogeny reveal phased pathogenic metamorphosis in Escherichia coli O2:H6. EMBO Mol. Med. 6, 347-357. doi: 10.1002/emmm.201303133

Boxall, A. B. (2004). The environmental side effects of medication. EMBO Rep. 5, 1110-1116. doi: 10.1038/sj.embor.7400307

Boyd, D., Peters, G. A., Cloeckaert, A., Boumedine, K. S., Chaslus-Dancla, E., Imberechts, H., et al. (2001). Complete nucleotide sequence of a 43-kilobase genomic island associated with the multidrug resistance region of serovar Typhimurium DT104 and its identification in phage type DT120 and serovar Agona. J. Bacteriol. 183, 5725-5732. doi: 10.1128/JB.183.19.5725-5732.2001

Bunny, K. L., Hall, R. M., and Stokes, H. W. (1995). New mobile gene cassettes containing an aminoglycoside resistance gene, aacA7, and a chloramphenicol resistance gene, catB3, in an integron in pBWH301. Antimicrob. Agents Chemother. 39, 686-693. doi: 10.1128/AAC.39.3.686

Cain, A. K., and Hall, R. M. (2012). Evolution of a multiple antibiotic resistance region in IncHIl plasmids: reshaping resistance regions in situ. J. Antimicrob. Chemother. 67, 2848-2853. doi: 10.1093/jac/dks317

Cain, A. K., Liu, X., Djordjevic, S. P., and Hall, R. M. (2010). Transposons related to Tn1696 in IncHI2 plasmids in multiply antibiotic resistant Salmonella enterica serovar Typhimurium from Australian animals. Microb. Drug Resist. 16, 197-202. doi: 10.1089/mdr.2010.0042

Castanon, J. I. (2007). History of the use of antibiotic as growth promoters in European poultry feeds. Poult. Sci. 86, 2466-2471. doi: 10.3382/ps.2007-00249

Cheng, W., Chen, H., Su, C., and Yan, S. (2013). Abundance and persistence of antibiotic resistance genes in livestock farms: a comprehensive investigation in eastern China. Environ. Int. 61, 1-7. doi: 10.1016/j.envint.2013.08.023

Collier, C., Smiricky-Tjardes, M., Albin, D., Wubben, J., Gabert, V., Deplancke, B., et al. (2003). Molecular ecological analysis of porcine ileal microbiota responses to antimicrobial growth promoters. J. Anim. Sci. 81, 3035-3045.

Costa, D., Poeta, P., Saenz, Y., Vinue, L., Coelho, A. C., Matos, M., et al. (2008). Mechanisms of antibiotic resistance in Escherichia coli isolates recovered from wild animals. Microb. Drug Resist. 14, 71-77. doi: 10.1089/mdr.2008.0795

Cox, L. A. Jr., and Popken, D. A. (2010). Assessing potential human health hazards and benefits from subtherapeutic antibiotics in the United States: tetracyclines as a case study. Risk Anal. 30, 432-457. doi: 10.1111/j.1539-6924.2009.01340.x

Davies, J., Spiegelman, G. B., and Yim, G. (2006). The world of subinhibitory antibiotic concentrations. Curr. Opin. Microbiol. 9, 445-453. doi: 10.1016/j.mib.2006.08.006

D’Costa, V. M., King, C. E., Kalan, L., Morar, M., Sung, W. W., Schwarz, C., et al. (2011). Antibiotic resistance is ancient. Nature 477, 457-461. doi: 10.1038 /nature 10388

Department of Heath and Department for Environment, Food, and Rural Affairs. (2013). UK Five Year Antimicrobial Resistance Strategy 2013 to 2018. London: Department of Health.

Dibner, J. J., and Richards, J. D. (2005). Antibiotic growth promoters in agriculture: history and mode of action. Poult. Sci. 84, 634-643. doi: 10.1093/ps/84.4.634

Djordjevic, S. P., Cain, A. K., Evershed, N. J., Falconer, L., Levings, R. S., Lightfoot, D., et al. (2009). Emergence and evolution of multiply antibiotic-resistant Salmonella enterica serovar Paratyphi B D-tartrate-utilizing strains containing 
SGI1. Antimicrob. Agents Chemother. 53, 2319-2326. doi: 10.1128/AAC. 01532-08

Djordjevic, S. P., Stokes, H. W., and Roy Chowdhury, P. (2013). Mobile elements, zoonotic pathogens and commensal bacteria: conduits for the delivery of resistance genes into humans, production animals and soil microbiota. Front. Microbiol. 4:86. doi: 10.3389/fmicb.2013.00086

Douard, G., Praud, K., Cloeckaert, A., and Doublet, B. (2010). The Salmonella genomic island 1 is specifically mobilized in trans by the IncA/C multidrug resistance plasmid family. PLoS ONE 5:e15302. doi: 10.1371/journal.pone.0015302

Dumonceaux, T., Hill, J., Hemmingsen, S., and Kessel, A. V. (2006). Characterization of intestinal microbiota and response to dietary virginiamycin supplementation in the broiler chicken. Appl. Environ. Microbiol. 72, 2815-2823. doi: 10.1128/AEM.72.4.2815-2823.2006

Elam, J. F., Jacobs, R. L., Tidwell, W. L., Gee, L. L., and Couch, J. R. (1953). Possible mechanism involved in the growth-promoting responses obtained from antibiotics. J. Nutr. 49, 307-317.

Eltayb, A., Barakat, S., Marrone, G., Shaddad, S., and Stalsby Lundborg, C. (2012). Antibiotic use and resistance in animal farming: a quantitative and qualitative study on knowledge and practices among farmers in Khartoum, Sudan. Zoonoses Public Health 59, 330-338. doi: 10.1111/j.1863-2378.2012.01458.x

FDA. (2011). Summary Report on Antimicrobials Sold or Distributed for Use in FoodProducing Animals. Food and Drug Administration Department of Health and Human Services.

Feighner, S. D., and Dashkevicz, M. P. (1987). Subtherapeutic levels of antibiotics in poultry feeds and their effects on weight gain, feed efficiency, and bacterial cholyltaurine hydrolase activity. Appl. Environ. Microbiol. 53, 331-336.

Forsberg, K. J., Reyes, A., Wang, B., Selleck, E. M., Sommer, M. O., and Dantas, G. (2012). The shared antibiotic resistome of soil bacteria and human pathogens. Science 337, 1107-1111. doi: 10.1126/science.1220761

Frank, C., Werber, D., Cramer, J. P., Askar, M., Faber, M., An Der Heiden, M., et al. (2011). Epidemic profile of Shiga-toxin-producing Escherichia coli O104:H4 outbreak in Germany. N. Engl. J. Med. 365, 1771-1780. doi: 10.1056/NEJMoa1 106483

Galvin, S., Boyle, F., Hickey, P., Vellinga, A., Morris, D., and Cormican, M. (2010). Enumeration and characterization of antimicrobial-resistant Escherichia coli bacteria in effluent from municipal, hospital, and secondary treatment facility sources. Appl. Environ. Microbiol. 76, 4772-4779. doi: 10.1128/AEM.02898-09

Ghosh, S., and Lapara, T. M. (2007). The effects of subtherapeutic antibiotic use in farm animals on the proliferation and persistence of antibiotic resistance among soil bacteria. ISME J. 1, 191-203. doi: 10.1038/ismej.2007.31

Gilbert, N. (2011). Antibiotic Resistance Marching Across Europe. Nature Publishing Group.

Gillings, M., Boucher, Y., Labbate, M., Holmes, A., Krishnan, S., Holley, M., et al. (2008). The evolution of class 1 integrons and the rise of antibiotic resistance. J. Bacteriol. 190, 5095-5100. doi: 10.1128/JB.00152-08

Goh, E. B., Yim, G., Tsui, W., McClure, J., Surette, M. G., and Davies, J. (2002). Transcriptional modulation of bacterial gene expression by subinhibitory concentrations of antibiotics. Proc. Natl. Acad. Sci. U.S.A. 99, 17025-17030. doi: $10.1073 /$ pnas. 252607699

Gootz, T. D. (2010). The global problem of antibiotic resistance. Crit. Rev. Immunol. 30, 79-93. doi: 10.1615/CritRevImmunol.v30.i1.60

Grad, Y. H., Godfrey, P., Cerquiera, G. C., Mariani-Kurkdjian, P., Gouali, M., Bingen, E., et al. (2013). Comparative genomics of recent Shiga toxin-producing Escherichia coli O104:H4: short-term evolution of an emerging pathogen. MBio 4, e00452-00412. doi: 10.1128/mBio.00452-12

Guban, J., Korver, D. R., Allison, G. E., and Tannock, G. W. (2006). Relationship of dietary antimicrobial drug administration with broiler performance, decreased population levels of Lactobacillus salivarius, and reduced bile salt deconjugation in the ileum of broiler chickens. Poult. Sci. 85, 2186-2194. doi: $10.1093 / \mathrm{ps} / 85.12 .2186$

Guerin, E., Cambray, G., Sanchez-Alberola, N., Campoy, S., Erill, I., Da Re, S., et al. (2009). The SOS response controls integron recombination. Science 324, 1034. doi: 10.1126/science. 1172914

Guerra, B., Fischer, J., and Helmuth, R. (2014). An emerging public health problem: acquired carbapenemase-producing microorganisms are present in foodproducing animals, their environment, companion animals and wild birds. Vet. Microbiol. 171, 290-297. doi: 10.1016/j.vetmic.2014.02.001

Hammerum, A. M., Jensen, L. B., and Aarestrup, F. M. (1998). Detection of the satA gene and transferability of virginiamycin resistance in Enterococcus faecium from food-animals. FEMS Microbiol. Lett. 168, 145-151. doi: 10.1016/S03781097(98)00433-9

Han, J. E., Kim, J. H., Choresca, C. H. Jr., Shin, S. P., Jun, J. W., Chai, J. Y., et al. (2012). Prevalence of tet gene and complete genome sequencing of tet gene-encoded plasmid (pAHH01) isolated from Aeromonas species in South Korea. J. Appl. Microbiol. 112, 631-638. doi: 10.1111/j.1365-2672.2012.05237.x

Hasman, H., and Aarestrup, F. M. (2002). tcrB, a gene conferring transferable copper resistance in Enterococcus faecium: occurrence, transferability, and linkage to macrolide and glycopeptide resistance. Antimicrob. Agents Chemother. 46, 1410-1416. doi: 10.1128/AAC.46.5.1410-1416.2002

Heo, J. M., Kim, J. C., Hansen, C. F., Mullan, B. P., Hampson, D. J., and Pluske, J. R. (2008). Effects of feeding low protein diets to piglets on plasma urea nitrogen, faecal ammonia nitrogen, the incidence of diarrhoea and performance after weaning. Arch. Anim. Nutr. 62, 343-358. doi: 10.1080/17450390802327811

Heuer, H., Kopmann, C., Binh, C. T., Top, E. M., and Smalla, K. (2009). Spreading antibiotic resistance through spread manure: characteristics of a novel plasmid type with low \%G+C content. Environ. Microbiol. 11, 937-949. doi: 10.1111/j.1462-2920.2008.01819.x

Heuer, H., Schmitt, H., and Smalla, K. (2011). Antibiotic resistance gene spread due to manure application on agricultural fields. Curr. Opin. Microbiol. 14, 236-243. doi: 10.1016/j.mib.2011.04.009

Hill, G. M., Cromwell, G. L., Crenshaw, T. D., Dove, C. R., Ewan, R. C., Knabe, D. A., et al. (2000). Growth promotion effects and plasma changes from feeding high dietary concentrations of zinc and copper to weanling pigs (regional study). J. Anim. Sci. 78, 1010-1016.

Hocquet, D., Llanes, C., Thouverez, M., Kulasekara, H. D., Bertrand, X., Plesiat, P., et al. (2012). Evidence for induction of integron-based antibiotic resistance by the SOS response in a clinical setting. PLoS Pathog. 8:e1002778. doi: 10.1371/journal.ppat.1002778

Hoffman, L. R., D’Argenio, D. A., Maccoss, M. J., Zhang, Z., Jones, R. A., and Miller, S. I. (2005). Aminoglycoside antibiotics induce bacterial biofilm formation. Nature 436, 1171-1175. doi: 10.1038/nature03912

Holman, D. B., and Chenier, M. R. (2013). Impact of subtherapeutic administration of tylosin and chlortetracycline on antimicrobial resistance in farrow-to-finish swine. FEMS Microbiol. Ecol. 85, 1-13. doi: 10.1111/1574-6941.12093

Holmes, A. J., Gillings, M. R., Nield, B. S., Mabbutt, B. C., Nevalainen, K. M., and Stokes, H. W. (2003). The gene cassette metagenome is a basic resource for bacterial genome evolution. Environ. Microbiol. 5, 383-394. doi: 10.1046/j.14622920.2003.00429.x

Hsu, J. T., Chen, C. Y., Young, C. W., Chao, W. L., Li, M. H., Liu, Y. H., et al. (2014). Prevalence of sulfonamide-resistant bacteria, resistance genes and integronassociated horizontal gene transfer in natural water bodies and soils adjacent to a swine feedlot in northern Taiwan. J. Hazard. Mater. 277, 34-43. doi: 10.1016/j.jhazmat.2014.02.016

Hughes, P., and Heritage, J. (2004). "Antibiotic growth-promoters in food animals," in FAO Animal Production and Health (Rome: Food and Agriculture Organisation of the United Nations).

Izat, A. L., Colberg, M., Reiber, M. A., Adams, M. H., Skinner, J. T., Cabel, M. C., et al. (1990). Effects of different antibiotics on performance, processing characteristics, and parts yield of broiler chickens. Poult. Sci. 69, 1787-1791. doi: $10.3382 / \mathrm{ps} .0691787$

Jacela, J. Y., Dritz, S. S., Tokach, M. D., Derouchey, J. M., Nelssen, J. L., Goodband, R. D., et al. (2008). Evaluation of commercial enzyme supplementation on growing pig performance. Kans. Agric. Exp. Stn.Prog. Rep. 1001 1001, $111-116$.

Jacob, M. E., Fox, J. T., Nagaraja, T. G., Drouillard, J. S., Amachawadi, R. G., and Narayanan, S. K. (2010). Effects of feeding elevated concentrations of copper and zinc on the antimicrobial susceptibilities of fecal bacteria in feedlot cattle. Foodborne Pathog. Dis. 7, 643-648. doi: 10.1089/fpd.2009.0401

Jacobs, R. L., Elam, J. F., Anderson, G. W., Gee, L. L., Fowler, J., and Couch, J. R. (1953). Further evidence as to the possible mechanism involved in the growthpromoting responses obtained from antibiotics. J. Nutr. 51, 507-513.

Januszkiewicz, A., Chrost, A., Wolkowicz, T., Madajczak, G., Wasiak, M., and Szych, J. (2011). Molecular investigation of enteroaggregative, shiga toxin-producing E. coli O104:H4 isolated in Poland during the recent international outbreakcharacteristic of epidemic clone. Med. Dosw. Mikrobiol. 63, 287-298.

Jensen, L. B., Hammerum, A. M., Poulsen, R. L., and Westh, H. (1999) Vancomycin-resistant Enterococcus faecium strains with highly similar pulsedfield gel electrophoresis patterns containing similar Tn1546-like elements 
isolated from a hospitalized patient and pigs in Denmark. Antimicrob. Agents Chemother. 43, 724-725.

Johnson, J. R., Johnston, B., Clabots, C., Kuskowski, M. A., and Castanheira, M. (2010). Escherichia coli sequence type ST131 as the major cause of serious multidrug-resistant E. coli infections in the United States. Clin. Infect. Dis. 51, 286-294. doi: 10.1086/653932

Kaplan, J. B., Izano, E. A., Gopal, P., Karwacki, M. T., Kim, S., Bose, J. L., et al. (2012). Low levels of beta-lactam antibiotics induce extracellular DNA release and biofilm formation in Staphylococcus aureus. MBio 3, e00198-00112. doi: 10.1128/mBio.00198-12

Kholodii, G. Y., Mindlin, S. Z., Bass, I. A., Yurieva, O. V., Minakhina, S. V., and Nikiforov, V. G. (1995). Four genes, two ends, and a res region are involved in transposition of Tn5053: a paradigm for a novel family of transposons carrying either a mer operon or an integron. Mol. Microbiol. 17, 1189-1200. doi: 10.1111/j.1365-2958.1995.mmi_17061189.x

Kieke, A. L., Borchardt, M. A., Kieke, B. A., Spencer, S. K., Vandermause, M. F., Smith, K. E., et al. (2006). Use of streptogramin growth promoters in poultry and isolation of streptogramin-resistant Enterococcus faecium from humans. J. Infect. Dis. 194, 1200-1208. doi: 10.1086/508189

Kim, H. B., Borewicz, K., White, B. A., Singer, R. S., Sreevatsan, S., Tu, Z. J., et al. (2012). Microbial shifts in the swine distal gut in response to the treatment with antimicrobial growth promoter, tylosin. Proc. Natl. Acad. Sci. U.S.A. 109, 15485-15490. doi: 10.1073/pnas.1205147109

Knarreborg, A., Lauridsen, C., Engberg, R. M., and Jensen, S. K. (2004). Dietary antibiotic growth promoters enhance the bioavailability of alphatocopheryl acetate in broilers by altering lipid absorption. J. Nutr. 134, 1487-1492.

Kolpin, D. W., Furlong, E. T., Meyer, M. T., Thurman, E. M., Zaugg, S. D., Barber, L. B., et al. (2002). Pharmaceuticals, hormones, and other organic wastewater contaminants in U.S. streams, 1999-2000: a national reconnaissance. Environ. Sci. Technol. 36, 1202-1211. doi: 10.1021/es011055j

Kunne, C., Billion, A., Mshana, S. E., Schmiedel, J., Domann, E., Hossain, H., et al. (2012). Complete sequences of plasmids from the hemolytic-uremic syndromeassociated Escherichia coli strain HUSEC41. J. Bacteriol. 194, 532-533. doi: 10.1128/JB.06368-11

Labar, A. S., Millman, J. S., Ruebush, E., Opintan, J. A., Bishar, R. A., Aboderin, A. O., et al. (2012). Regional dissemination of a trimethoprim-resistance gene cassette via a successful transposable element. PLOS ONE 7:e38142. doi: 10.1371/journal.pone.0038142

Labbate, M., Roy Chowdhury, P., and Stokes, H. W. (2008). A class 1 integron present in a human commensal has a hybrid transposition module compared to Tn402: evidence of interaction with mobile DNA from natural environments. J. Bacteriol. 190, 5318-5327. doi: 10.1128/JB.00199-08

Leavis, H. L., Willems, R. J., Top, J., Spalburg, E., Mascini, E. M., Fluit, A. C., et al. (2003). Epidemic and nonepidemic multidrug-resistant Enterococcus faecium. Emerg. Infect. Dis. 9, 1108-1115. doi: 10.3201/eid0909.020383

Le Hello, S., Hendriksen, R. S., Doublet, B., Fisher, I., Nielsen, E. M., Whichard, J. M., et al. (2011). International spread of an epidemic population of Salmonella enterica serotype Kentucky ST198 resistant to ciprofloxacin. J. Infect. Dis. 204, 675-684. doi: 10.1093/infdis/jir409

Le Hello, S., Weill, F. X., Guibert, V., Praud, K., Cloeckaert, A., and Doublet, B. (2012). Early strains of multidrug-resistant Salmonella enterica serovar Kentucky sequence type 198 from Southeast Asia harbor Salmonella genomic island 1-J variants with a novel insertion sequence. Antimicrob. Agents Chemother. 56, 5096-5102. doi: 10.1128/AAC.00732-12

Lee, C. K., Kamitani, Y., Nihira, T., and Yamada, Y. (1999). Identification and in vivo functional analysis of a virginiamycin $\mathrm{S}$ resistance gene (varS) from Streptomyces virginiae. J. Bacteriol. 181, 3293-3297.

Levings, R. S., Djordjevic, S. P., and Hall, R. M. (2008). SGI2, a relative of Salmonella genomic island SGI1 with an independent origin. Antimicrob. Agents Chemother. 52, 2529-2537. doi: 10.1128/AAC.00189-08

Levings, R. S., Lightfoot, D., Hall, R. M., and Djordjevic, S. P. (2006). Aquariums as reservoirs for multidrug-resistant Salmonella Paratyphi B. Emerg. Infect. Dis. 12, 507-510. doi: 10.3201/eid1203.051085

Levings, R. S., Lightfoot, D., Partridge, S. R., Hall, R. M., and Djordjevic, S. P. (2005). The genomic island SGI1, containing the multiple antibiotic resistance region of Salmonella enterica serovar Typhimurium DT104 or variants of it, is widely distributed in other S. enterica serovars. J. Bacteriol. 187, 4401-4409. doi: 10.1128/JB.187.13.4401-4409.2005
Levings, R. S., Partridge, S. R., Djordjevic, S. P., and Hall, R. M. (2007). SGI1$\mathrm{K}$, a variant of the SGIl genomic island carrying a mercury resistance region, in Salmonella enterica serovar Kentucky. Antimicrob. Agents Chemother. 51, 317-323. doi: 10.1128/AAC.01229-06

Li, L., Sun, J., Liu, B., Zhao, D., Ma, J., Deng, H., et al. (2013). Quantification of lincomycin resistance genes associated with lincomycin residues in waters and soils adjacent to representative swine farms in China. Front. Microbiol. 4:364. doi: $10.3389 /$ fmicb. 2013.00364

Li, Y., Tomita, H., Lv, Y., Liu, J., Xue, F., Zheng, B., et al. (2011). Molecular characterization of erm(B)- and mef(E)-mediated erythromycin-resistant Streptococcus pneumoniae in China and complete DNA sequence of Tn2010. J. Appl. Microbiol. 110, 254-265. doi: 10.1111/j.1365-2672.2010.04875.x

Liebert, C. A., Hall, R. M., and Summers, A. O. (1999). Transposon Tn21, flagship of the floating genome. Microbiol. Mol. Biol. Rev. 63, 507-522.

Lin, J., Yan, M., Sahin, O., Pereira, S., Chang, Y. J., and Zhang, Q. (2007). Effect of macrolide usage on emergence of erythromycin-resistant Campylobacter isolates in chickens. Antimicrob. Agents Chemother. 51, 1678-1686. doi: 10.1128/AAC.01411-06

Maron, D. F., Smith, T. J., and Nachman, K. E. (2013). Restrictions on antimicrobial use in food animal production: an international regulatory and economic survey. Global. Health 9:48. doi: 10.1186/1744-8603-9-48

Mathers, J. J., Flick, S. C., and Cox, L. A. Jr. (2011). Longer-duration uses of tetracyclines and penicillins in U.S. food-producing animals: indications and microbiologic effects. Environ. Int. 37, 991-1004. doi: 10.1016/j.envint.2011.01.014

Mcintosh, D., Cunningham, M., Ji, B., Fekete, F. A., Parry, E. M., Clark, S. E., et al. (2008). Transferable, multiple antibiotic and mercury resistance in Atlantic Canadian isolates of Aeromonas salmonicida subsp. salmonicida is associated with carriage of an IncA/C plasmid similar to the Salmonella enterica plasmid pSN254. J. Antimicrob. Chemother. 61, 1221-1228. doi: 10.1093/jac/dkn123

Marquez, C., Labbate, M., Ingold, A. J., Roy Chowdhury, P., Ramirez, M. S., Centron, D., et al. (2008). Recovery of a functional class 2 integron from an Escherichia coli strain mediating a urinary tract infection. Antimicrob. Agents Chemother. 52, 4153-4154. doi: 10.1128/AAC.00710-08

Martinez, E., Djordjevic, S. P., Stokes, H. W., and Roy Chowdhury, P. (2013). Mobilized Integrons: Team Players in the Spread of Antibiotic Resistance Genes. New York, NY: Springer.

Minakhina, S., Kholodii, G., Mindlin, S., Yurieva, O., and Nikiforov, V. (1999). Tn5053 family transposons are res site hunters sensing plasmidal res sites occupied by cognate resolvases. Mol. Microbiol. 33, 1059-1068. doi: 10.1046/j.13652958.1999.01548.x

Mirzaagha, P., Louie, M., Sharma, R., Yanke, L. J., Topp, E., and McAllister, T. A. (2011). Distribution and characterization of ampicillin- and tetracyclineresistant Escherichia coli from feedlot cattle fed subtherapeutic antimicrobials. BMC Microbiol. 11:78. doi: 10.1186/1471-2180-11-78

Monteiro, S. C., and Boxall, A. B. (2009). Factors affecting the degradation of pharmaceuticals in agricultural soils. Environ. Toxicol. Chem. 28, 2546-2554. doi: 10.1897/08-657.1

Muhl, A., and Liebert, F. (2007). Growth and parameters of microflora in intestinal and faecal samples of piglets due to application of a phytogenic feed additive. J. Anim. Physiol. Anim. Nutr. (Berl). 91, 411-418. doi: 10.1111/j.14390396.2006.00668.x

Nandi, S., Maurer, J. J., Hofacre, C., and Summers, A. O. (2004). Gram-positive bacteria are a major reservoir of Class 1 antibiotic resistance integrons in poultry litter. Proc. Natl. Acad. Sci. U.S.A. 101, 7118-7122. doi: 10.1073/pnas.03064 66101

Nortey, T. N., Patience, J. F., Simmins, P. H., Trottier, N. L., and Zijlstra, R. T. (2007). Effects of individual or combined xylanase and phytase supplementation on energy, amino acid, and phosphorus digestibility and growth performance of grower pigs fed wheat-based diets containing wheat millrun. J. Anim. Sci. 85, 1432-1443. doi: 10.2527/jas.2006-613

Ohimain, E. I., and Ofongo, R. T. S. (2012). The effect of probiotic and prebiotic feed supplementation on chicken health and gut microflora: a review. Int. J. Anim. Vererinary Adv. 4, 135-143.

Ojer-Usoz, E., Gonzalez, D., Garcia-Jalon, I., and Vitas, A. I. (2014). High dissemination of extended-spectrum beta-lactamase-producing Enterobacteriaceae in effluents from wastewater treatment plants. Water Res. 56C, 37-47. doi: 10.1016/j.watres.2014.02.041

Parkhill, J., Dougan, G., James, K. D., Thomson, N. R., Pickard, D., Wain, J., et al. (2001). Complete genome sequence of a multiple drug resistant 
Salmonella enterica serovar Typhi CT18. Nature 413, 848-852. doi: 10.1038/351 01607

Partridge, S. R., Brown, H. J., Stokes, H. W., and Hall, R. M. (2001). Transposons Tn1696 and Tn21 and their integrons In4 and In 2 have independent origins. Antimicrob. Agents Chemother. 45, 1263-1270. doi: 10.1128/AAC.45.4.12631270.2001

Patterson, J. A., and Burkholder, K. M. (2003). Application of prebiotics and probiotics in poultry production. Poult. Sci. 82, 627-631. doi: 10.1093/ps/ 82.4 .627

Pluske, J. R. (2013). Feed- and feed additives-related aspects of gut health and development in weanling pigs. J. Anim. Sci. Biotechnol. 4:1. doi: 10.1186/20491891-4-1

Poeta, P., Radhouani, H., Sargo, R., and Igrejas, G. (2008). In vitro activity of dalbavancin against enterococci isolates from wild animals, pets, poultry and humans in Portugal. J. Basic Microbiol. 48, 526-528. doi: 10.1002/jobm.200800146

Popowska, M., and Krawczyk-Balska, A. (2013). Broad-host-range IncP1 plasmids and their resistance potential. Front. Microbiol. 4:44. doi: 10.3389/fmicb.2013.00044

Prager, R., Lang, C., Aurass, P., Fruth, A., Tietze, E., and Flieger, A. (2014). Two novel EHEC/EAEC hybrid strains isolated from human infections. PLoS ONE 9:e95379. doi: 10.1371/journal.pone.0095379

Price, L. B., Johnson, J. R., Aziz, M., Clabots, C., Johnston, B., Tchesnokova, V., et al. (2013). The epidemic of extended-spectrum-beta-lactamaseproducing Escherichia coli ST131 is driven by a single highly pathogenic subclone, H30-Rx. MBio 4, e00377-00313. doi: 10.1128/mBio. 00377-13

Radosavljevic, V., Finke, E. J., and Belojevic, G. (2014). Escherichia coli O104:H4 outbreak in Germany-clarification of the origin of the epidemic. Eur. J. Public Health doi: 10.1093/eurpub/cku048. [Epub ahead of print].

Ragland, D., Schneider, J., Stevenson, D., Hill, M. A., and Bakker, M. (2007). Oregano oil as an alternative to antimicrobials in nursery diets. J. Swine Health Prod. 15, 346-351.

Recchia, G. D., and Hall, R. M. (1995). Gene cassettes: a new class of mobile element. Microbiology 141(Pt 12), 3015-3027. doi: 10.1099/13500872-14112-3015

Romero, D., Traxler, M. F., Lopez, D., and Kolter, R. (2011). Antibiotics as signal molecules. Chem. Rev. 111, 5492-5505. doi: 10.1021/cr2000509

Ramos, S., Igrejas, G., Rodrigues, J., Capelo-Martinez, J. L., and Poeta, P. (2012). Genetic characterisation of antibiotic resistance and virulence factors in vanA-containing enterococci from cattle, sheep and pigs subsequent to the discontinuation of the use of avoparcin. Vet. J. 193, 301-303. doi: 10.1016/j.tvjl.2011.12.007

Roy Chowdhury, P., Ingold, A., Vanegas, N., Martinez, E., Merlino, J., Merkier, A. K., et al. (2011). Dissemination of multiple drug resistance genes by class 1 integrons in Klebsiella pneumoniae isolates from four countries: a comparative study. Antimicrob. Agents Chemother. 55, 3140-3149. doi: 10.1128/AAC. 01529-10

Roy Chowdhury, P., Merlino, J., Labbate, M., Cheong, E. Y., Gottlieb, T., and Stokes, H. W. (2009). Tn6060, a transposon from a genomic island in a Pseudomonas aeruginosa clinical isolate that includes two class 1 integrons. Antimicrob. Agents Chemother. 53, 5294-5296. doi: 10.1128/AAC.00687-09

Sarmah, A. K., Meyer, M. T., and Boxall, A. B. (2006). A global perspective on the use, sales, exposure pathways, occurrence, fate and effects of veterinary antibiotics (VAs) in the environment. Chemosphere 65, 725-759. doi: 10.1016/j.chemosphere.2006.03.026

Schmitt, R., Bernhard, E., and Mattes, R. (1979). Characterisation of Tn1721, a new transposon containing tetracycline resistance genes capable of amplification. Mol. Gen. Genet. 172, 53-65. doi: 10.1007/BF00276215

Schone, F., Vetter, A., Hartung, H., Bergmann, H., Biertumpfel, A., Richter, G., et al. (2006). Effects of essential oils from fennel (Foeniculi aetheroleum) and caraway (Carvi aetheroleum) in pigs. J. Anim. Physiol. Anim. Nutr. (Berl). 90, 500-510. doi: 10.1111/j.1439-0396.2006.00632.x

Seiler, C., and Berendonk, T. U. (2012). Heavy metal driven co-selection of antibiotic resistance in soil and water bodies impacted by agriculture and aquaculture. Front. Microbiol. 3:399. doi: 10.3389/fmicb.2012.00399

Shi, L., Zheng, M., Xiao, Z., Asakura, M., Su, J., Li, L., et al. (2006). Unnoticed spread of class 1 integrons in gram-positive clinical strains isolated in Guangzhou, China. Microbiol. Immunol. 50, 463-467. doi: 10.1111/j.13480421.2006.tb03815.x
Simoes, R. R., Poirel, L., Da Costa, P. M., and Nordmann, P. (2010). Seagulls and beaches as reservoirs for multidrug-resistant Escherichia coli. Emerging Infect. Dis. 16, 110-112. doi: 10.3201/eid1601.090896

Stevens, A. M., Shoemaker, N. B., Li, L. Y., and Salyers, A. A. (1993). Tetracycline regulation of genes on Bacteroides conjugative transposons. J. Bacteriol. 175, 6134-6141.

Stokes, H. W., and Gillings, M. R. (2011). Gene flow, mobile genetic elements and the recruitment of antibiotic resistance genes into Gram-negative pathogens. FEMS Microbiol. Rev. 35, 790-819. doi: 10.1111/j.1574-6976.2011.00273.x

Stokes, H. W., and Hall, R. M. (1989). A novel family of potentially mobile DNA elements encoding site-specific gene-integration functions: integrons. Mol. Microbiol. 3, 1669-1683. doi: 10.1111/j.1365-2958.1989.tb00153.x

Stokes, H. W., Nesbo, C. L., Holley, M., Bahl, M. I., Gillings, M. R., and Boucher, Y. (2006). Class 1 integrons potentially predating the association with tn402-like transposition genes are present in a sediment microbial community. J. Bacteriol. 188, 5722-5730. doi: 10.1128/JB.01950-05

Subrt, N., Mesak, L. R., and Davies, J. (2011). Modulation of virulence gene expression by cell wall active antibiotics in Staphylococcus aureus. J. Antimicrob. Chemother. 66, 979-984. doi: 10.1093/jac/dkr043

Szczepanowski, R., Braun, S., Riedel, V., Schneiker, S., Krahn, I., Puhler, A., et al. (2005). The 120592 bp IncF plasmid pRSB107 isolated from a sewagetreatment plant encodes nine different antibiotic-resistance determinants, two iron-acquisition systems and other putative virulence-associated functions. Microbiology 151, 1095-1111. doi: 10.1099/mic.0.27773-0

Szczepanowski, R., Linke, B., Krahn, I., Gartemann, K. H., Gutzkow, T., Eichler, W., et al. (2009). Detection of 140 clinically relevant antibiotic-resistance genes in the plasmid metagenome of wastewater treatment plant bacteria showing reduced susceptibility to selected antibiotics. Microbiology 155, 2306-2319. doi: 10.1099/mic.0.028233-0

Tennstedt, T., Szczepanowski, R., Krahn, I., Puhler, A., and Schluter, A. (2005). Sequence of the 68,869 bp IncP-lalpha plasmid pTB11 from a waste-water treatment plant reveals a highly conserved backbone, a Tn402like integron and other transposable elements. Plasmid 53, 218-238. doi: 10.1016/j.plasmid.2004.09.004

Toleman, M. A., and Walsh, T. R. (2011). Combinatorial events of insertion sequences and ICE in Gram-negative bacteria. FEMS Microbiol. Rev. 35, 912-935. doi: 10.1111/j.1574-6976.2011.00294.x

Torres, O. R., Korman, R. Z., Zahler, S. A., and Dunny, G. M. (1991). The conjugative transposon Tn925: enhancement of conjugal transfer by tetracycline in Enterococcus faecalis and mobilization of chromosomal genes in Bacillus subtilis and E. faecalis. Mol. Gen. Genet. 225, 395-400. doi: 10.1007/BF00261679

Toval, F., Kohler, C. D., Vogel, U., Wagenlehner, F., Mellmann, A., Fruth, A., et al. (2014). Characterization of Escherichia coli isolates from hospital inpatients or outpatients with urinary tract infection. J. Clin. Microbiol. 52, 407-418. doi: 10.1128/JCM.02069-13

Tremblay, C. L., and Archambault, M. (2013). Interference in pheromoneresponsive conjugation of a high-level bacitracin resistant Enterococcus faecalis plasmid of poultry origin. Int. J. Environ. Res. Public Health 10, 4245-4260. doi: 10.3390/ijerph10094245

Tsuda, H., Yamashita, Y., Shibata, Y., Nakano, Y., and Koga, T. (2002). Genes involved in bacitracin resistance in Streptococcus mutans. Antimicrob. Agents Chemother. 46, 3756-3764. doi: 10.1128/AAC.46.12.3756-3764.2002

Venturini, C., Beatson, S. A., Djordjevic, S. P., and Walker, M. J. (2010). Multiple antibiotic resistance gene recruitment onto the enterohemorrhagic Escherichia coli virulence plasmid. FASEB J. 24, 1160-1166. doi: 10.1096/fj.09144972

Venturini, C., Hassan, K. A., Roy Chowdhury, P., Paulsen, I. T., Walker, M. J., and Djordjevic, S. P. (2013). Sequences of two related multiple antibiotic resistance virulence plasmids sharing a unique IS26-related molecular signature isolated from different Escherichia coli pathotypes from different hosts. PLoS ONE 8:e78862. doi: 10.1371/journal.pone.0078862

Wang, Z., Zeng, X., Mo, Y., Smith, K., Guo, Y., and Lin, J. (2012). Identification and characterization of a bile salt hydrolase from Lactobacillus salivarius for development of novel alternatives to antibiotic growth promoters. Appl. Environ. Microbiol. 78, 8795-8802. doi: 10.1128/AEM.02519-12

Watanabe, N., Bergamaschi, B. A., Loftin, K. A., Meyer, M. T., and Harter, T. (2010). Use and environmental occurrence of antibiotics in freestall dairy farms with manured forage fields. Environ. Sci. Technol. 44, 6591-6600. doi: $10.1021 /$ es $100834 \mathrm{~s}$ 
Wendlandt, S., Kadlec, K., Feßler, A. T., Van Duijkeren, E., and Schwarz, S. (2014). Two different erm(C)-carrying plasmids in the same methicillin-resistant Staphylococcus aureus CC398 isolate from a broiler farm. Vet. Microbiol. 171, 382-387. doi: 10.1016/j.vetmic.2014.01.009

Wellington, E. M., Boxall, A. B., Cross, P., Feil, E. J., Gaze, W. H., Hawkey, P. M., et al. (2013). The role of the natural environment in the emergence of antibiotic resistance in gram-negative bacteria. Lancet Infect. Dis. 13, 155-165. doi: 10.1016/S1473-3099(12)70317-1

WHO. (2014). Antimicrobial Resistance: Global Report on Surveillance. Geneva: World Health Organisation; WHO Press.

Wibberg, D., Szczepanowski, R., Eikmeyer, F., Puhler, A., and Schluter, A. (2013). The IncF plasmid pRSB225 isolated from a municipal wastewater treatment plant's on-site preflooder combining antibiotic resistance and putative virulence functions is highly related to virulence plasmids identified in pathogenic E. coli isolates. Plasmid 69, 127-137. doi: 10.1016/j.plasmid.2012. 11.001

Wu, S., Dalsgaard, A., Hammerum, A. M., Porsbo, L. J., and Jensen, L. B. (2010). Prevalence and characterization of plasmids carrying sulfonamide resistance genes among Escherichia coli from pigs, pig carcasses and human. Acta. Vet. Scand. 52:47. doi: 10.1186/1751-0147-52-47

$\mathrm{Xu}$, Z., Li, L., Shi, L., and Shirtliff, M. E. (2011). Class 1 integron in staphylococci. Mol. Biol. Rep. 38, 5261-5279. doi: 10.1007/s11033-0110676-7

Xu, Z., Li, L., Shirtliff, M. E., Peters, B. M., Peng, Y., Alam, M. J., et al. (2010). First report of class 2 integron in clinical Enterococcus faecalis and class 1 integron in Enterococcus faecium in South China. Diagn. Microbiol. Infect. Dis. 68, 315-317. doi: 10.1016/j.diagmicrobio.2010.05.014

Yamina, B., Tahar, B., and Marie Laure, F. (2012). Isolation and screening of heavy metal resistant bacteria from wastewater: a study of heavy metal co-resistance and antibiotics resistance. Water Sci. Technol. 66, 2041-2048. doi: 10.2166/wst.2012.355

Zhu, Y. G., Johnson, T. A., Su, J. Q., Qiao, M., Guo, G. X., Stedtfeld, R. D., et al. (2013). Diverse and abundant antibiotic resistance genes in Chinese swine farms. Proc. Natl. Acad. Sci. U.S.A. 110, 3435-3440. doi: 10.1073/pnas.12227 43110

Zhu, W., Murray, P. R., Huskins, W. C., Jernigan, J. A., Mcdonald, L. C., Clark, N. C., et al. (2010). Dissemination of an Enterococcus Inc18-Like vanA plasmid associated with vancomycin-resistant Staphylococcus aureus. Antimicrob. Agents Chemother. 54, 4314-4320. doi: 10.1128/AAC.00185-10

Conflict of Interest Statement: The authors declare that the research was conducted in the absence of any commercial or financial relationships that could be construed as a potential conflict of interest.

Received: 08 April 2014; accepted: 14 July 2014; published online: 12 August 2014. Citation: Roy Chowdhury P, McKinnon J, Wyrsch E, Hammond JM, Charles IG and Djordjevic SP (2014) Genomic interplay in bacterial communities: implications for growth promoting practices in animal husbandry. Front. Microbiol. 5:394. doi: 10.3389/fmicb.2014.00394

This article was submitted to Antimicrobials, Resistance and Chemotherapy, a section of the journal Frontiers in Microbiology.

Copyright (c) 2014 Roy Chowdhury, McKinnon, Wyrsch, Hammond, Charles and Djordjevic. This is an open-access article distributed under the terms of the Creative Commons Attribution License (CC BY). The use, distribution or reproduction in other forums is permitted, provided the original author(s) or licensor are credited and that the original publication in this journal is cited, in accordance with accepted academic practice. No use, distribution or reproduction is permitted which does not comply with these terms. 